\title{
Pengaruh Penggunaan Instagram Terhadap Karakter Peserta Didik di Kelas X SMA Negeri 3 Parepare
}

\author{
Salmiati ${ }^{1}$, Yustia Ningsi ${ }^{2}$, Ramlah $^{3}$ \\ 1salmiatifai@gmail.com, yustianingsih07@gmail.com, ${ }^{3}$ ramlahbpi@gmail.com \\ ${ }^{1}$ Universitas Muhammadiyah Parepare \\ ${ }^{2}$ Universitas Muhammadiyah Parepare \\ ${ }^{3}$ Universitas Muhammadiyah Parepare
}

\begin{abstract}
The research consists of three research problems; (1) in what way is Instagram used, (2) what is the character of students, and (3) is there significant effect of Instagram toward the students' character in class X at SMA Negeri 3 Parepare. The research applied survey research. The technique of data collection used questionnaire, interview, and observation. The population of the research involved as many as 46 class $X$ students. The result of the research revealed (1) that the intensity of the use of Instagram by the students of class X of SMA Negeri 3 Parepare was in high category. It was shown by the questionnaire result which was $45,2 \%$. The value was in the interval between $26 \%$ - $50 \%$ which was high, (2) The character of the class X students of SMA Negeri 3 Parepare was in good category. It was shown by the questionnaire result which was $49,8 \%$. The value was in the interval between $26 \%$ - 50\% which was good, (3) The effect of Instagram toward the character of class X students of SMA Negeri 3 Parepare can be concluded having positive effect based on the calculation using product moment and interview technique. As general reveal of the research, the intensity of the use of Instagram has positive effect toward the character of class X students of SMA Negeri 3 Parepare.
\end{abstract}

\section{Keywords: Instagram, Character of students}

\begin{abstract}
ABSTRAK
Penelitian ini bertujuan untuk mendapatkan gambaran tentang penggunaan Instagram dan mengetahui karakter peserta didik di Kelas X SMA Negeri 3 Parepare. Disamping itu, untuk mengetahui pengaruh positif atau negatif media sosial Instagram terhadap karakter peserta didik khususnya di kelas X IPA I SMA Negeri 3 Parepare. Rumusan masalah dalam penelitian ini adalah bagaimana penggunaan instagram, bagaimana karakter peserta didik dan apakah ada pengaruh penggunaan instagram terhadap karakter peserta didik di kelas X SMA Negeri 3 Parepare. Penelitian ini menggunakan pendekatan survei. Teknik pengumpulan data pada penelitian ini menggunakan angket/kuesioner, wawancara, dan observasi. Populasi dari penelitian ini meliputi peserta didik kelas X sebanyak 46 orang. Hasil penelitian menunjukkan (1) intensitas penggunaan instagram oleh peserta didik dikelas X SMA Negeri 3 Parepare termasuk dalam kategori cukup tinggi. Hal ini terbukti dengan hasil angket yang memiliki nilai rata-rata 45, 2\%. Nilai tersebut berada dalam interval 26\% - 50\% yang masuk dalam kategori cukup tinggi, (2) Karakter peserta didik di kelas X SMA Negeri 3 Parepare termasuk dalam kategori cukup baik. Hal initerbuktidenganhasilangket yang memiliki rata-rata 49. 8\%. Nilaitersebutberadadalam interval 26\% - 50\%yang masukdalamkategoricukupbaik. Adapun pengaruh instagramterhadap karakter peserta didik kelas X SMA Negeri 3 Parepare dapat disimpulkan bahwa terdapat korelasi positif yang signifikan berdasarkan perhitungan dengan menggunakan teknik korelasiproduct moment dan teknik wawancara. Secara umum
\end{abstract}


intensitas penggunaan instagram cukup tinggi di kelas X SMA Negeri 3 Parepare. Adanya instagramberdampak terhadap karakterpesertadidik baik positif maupun negatif.

\section{Kata kunci: Instagram, Karakter Peserta Didik.}

Media sosial adalah sebuah media online, para penggunanya dapat dengan mudah berpartisipasi, berbagi, dan menciptakan isi meliputi blog, jejaring sosial, wiki, forum dan dunia virtual yang paling umum digunakan oleh masyarakat di seluruh dunia. Bertambahnya pengguna sosial media, juga membuat banyak orang yang tersandung kasus-kasus hukum karena salah dalam menggunakan sosial media seperti menyebar kebencian, mengancam, menyebar informasi bohong, dan lain-lain. Sebagaimana yang tercantum dalam Undang-Undang Pasal 45Ayat 2;"Setiap orang yang dengan sengaja dan tanpa hak menyebarkan informasi yang ditujukan untuk menimbulkan rasa kebencian atau permusuhan individu dan/atau kelompok masyarakat tertentu berdasarkan atas suku, agama, ras, dan antargolongan (SARA) sebagaimana dimaksud dalam Pasal 28 Ayat (2) dipidana dengan pidana penjara paling lama 6 (enam) tahun dan/ atau denda paling banyak Rp. 1.000.000.000,00 (satu miliar rupiah). "1

Salah satu media sosial yang sedang diminati oleh para remaja adalah Instagram. Menurut Bambang Dwi Atmoko, seorang pakar teknologi telekomunikasi, menyatakan bahwa: “Instagram adalah sebuah aplikasi dari smartphone yang khusus untuk media sosial yang merupakan salah satu dari media digital yang mempunyai fungsi hampir sama dengan twitter, namun perbedaannya

\footnotetext{
${ }^{1}$ Vindisiari Putri, Aturan UU IT, 2017 (https://www. brilio. net/serius/6-aturan-di-uu-iteini-perlu-kamu-tahu-agar-aman-saat-bermedsos-

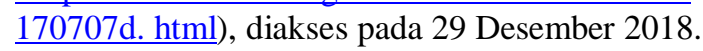

terletak pada pengambilan foto dalam bentuk atau tempat untuk berbagi informasi terhadap penggunanya. Instagram juga dapat memberikan inspirasi bagi penggunanya dan juga dapat meningkatkan kreatifitas, karena instagram mempunyai fitur yang dapat membuat foto menjadi lebih indah, lebih artistik dan menjadi lebih bagus. $^{2}$

Pembentukan karakter yang religius sejalan dengan tujuan pendidikan nasional yang telah termaktub dalam UndangUndang Nomor 20 Tahun 2003 tentang Sistem Pendidikan Nasional Pasal 3 yaitu: “Tujuan pendidikan nasional adalah mengembangkan potensi peserta didik agar menjadi manusia yang beriman dan bertakwa kepada Tuhan Yang Maha Esa, berakhlak mulia, sehat, berilmu, cakap, kreatif, mandiri, dan menjadi warga negara yang demokratis serta bertanggung jawab". 3

\section{TINJAUAN PUSTAKA}

\section{a. Hubungan Dengan Penelitian Sebelumnya}

Berdasarkan survei yang penulis lakukan, ada beberapa kajian yang relevan dengan penelitian ini. Penelitian-penelitian tersebut antara lain adalah sebagai berikut:

Pertama Jurnal Edukasi yang ditulis oleh Nisa Khairuni, mahasiswi pascasarjana UIN Ar-Raniry Banda Aceh yang berjudul “Dampak Positif dan Negatif Sosial Media

${ }^{2}$ Bambang Dwi Atmoko, Instagram Handbook Tips Fotografi Ponsel. (Jakarta: Media Kita, 2012), h. 6.

${ }^{3}$ Republik Indonesia, Undang-Undang RI. Nomor 20 Tahun 2003tentang Sistem Pendidikan Nasional, bab II, pasal 3 ayat 1. 
Terhadap Akhlak Anak (Studi Kasus di SMPN 2 Kelas VIII Banda Aceh)”. ${ }^{4}$ Fokus penelitian pada jurnal tersebut yaitu dampak positif dan negatif dari media sosial antara lain facebook, twitter dan instagram, dan objek kajiannya adalah anak-anak. Sedangkan penulis pada penelitian ini fokus pada pengaruh positif dari instagram terhadap pembentukan akhlak dan objek kajiannya adalah peserta didik.

Kedua adalah Jurnal Makara Sosial Humaniora yang ditulis oleh Nidya Zahra Hayumi (2014) mahasiswa Universitas Indonesia (UI) yang berjudul "Penggunaan Instagram Sebagai Bentuk Eksistensi Diri”. ${ }^{5}$ Penelitian ini menggunakan pendekatan kualitatif dan fokus pada eksistensi diri, sedangkan penulis menggunakan pendekatan kuantitatif dan fokus pada Pengaruh Penggunaan Instagram Terhadap Pembentukan Karakter yang Islami.

Keempat Jurnal Komunikasi Profetik yang ditulis oleh Rama Kertamukti (2015) dosen ilmu komunikasi UIN Sunan Kalijaga yang berjudul "Instagram dan Pembentukan Citra (Studi Kualitatif Komunikasi Visual dalam Pembentukan Personal Karakter Account Instagram @Basukibtp)”6 Penelitian ini menggunakan pendekatan kualitatif dan fokus pada pembentukan citra atau personal karakter

${ }^{4}$ Nisa Khairuni, Dampak Positif Dan Negatif Sosial Media Terhadap Akhlak Anak (Studi Kasus di SMP N 2 Kelas VIII Banda Aceh), (Jurnal, mahasiswi pascasarjana UIN Ar-Raniry Banda Aceh, 2016).

${ }^{5}$ Nidya Zahra Hayumi, Penggunaan Instagram Sebagai Bentuk Eksistensi Diri, (Jurnal, mahasiswi Universitas Indonesia, 2014).

${ }^{6}$ Rama Mukti, Instagram dan Pembentukan Citra (Studi Kualitatif Komunikasi Visual dalam Pembentukan Persolan Karakter Account Instagram @Basukibtp), (Jurnal, Dosen UIN Kalijaga, 2015). account instagram @Basukibtp. Sedangkan penulis pada penelitian ini fokus padapengaruh positif dari instagram terhadap pembentukan akhlak dan objek kajiannya adalah peserta didik.

\section{b. Landasan Teori}

1. Instagram

Instagram adalah sebuah aplikasi media sosial yang memungkinkan pengguna untuk mengambil foto dan video, menerapkan filter digital (pemberian efek pada foto) dan membagikannya ke berbagai media sosial termasuk instagram itu sendiri. $^{7}$ Instagram dapat diartikan menampilkan dan menyampaikan informasi berupa foto atau gambar secara cepat lewat aplikasi yang dapat diakses oleh orang lain. Tentunya, agar dapat menggunakan aplikasi instagram, selain menginstall melalui Play Store milik Google atau Apple Store, perlu terhubung terlebih dahulu dengan koneksi internet.

Instagram berasal dari pengertian keseluruhan fungsi aplikasi ini. Kata "insta" berasal dari kata "instan", seperti kamera polaroid yang pada masanya lebih dikenal dengan sebutan "foto instan". Instagram juga dapat menampilkan foto-foto secara instan, seperti polaroid di dalam tampilannya. Sedangkan untuk kata "gram" berasal dari kata "telegram" yang cara kerjanya untuk mengirimkan informasi kepada orang lain dengan cepat. Sama halnya dengan instagram yang dapat mengunggah foto dengan menggunakan jaringan Internet, sehingga informasi yang ingin disampaikan dapat diterima dengan cepat. Oleh karena itulah instagram

\footnotetext{
${ }^{7}$ Michelle Wifalin, Efektivitas Instagram Common Grounds, Jurnal E-Komunikasi Program Studi Ilmu Komunikasi Universitas Petra Surabaya.
} 
merupakan gabungan dari kata instan dan telegram. ${ }^{8}$

Sebagai suatu aplikasi di media sosial instagram banyak memiliki manfaat dan kelebihan, tetapi juga mempunyai suatu dampak yang buruk pula. Citra diri seseorang dapat terbentuk ketika mengunggah sebuah foto mengenai dirinya di halaman instagram. Instagram adalah bagian dari komunikasi visual yang dapat membangun citra seseorang. ${ }^{9}$

Citra merupakan hasil evaluasi dalam diri seseorang berdasarkan persepsi dan pemahaman terhadap gambaran yang telah diolah, diorganisasikan, dan disimpan dalam benak seseorang. Citra dapat diukur melalui pendapat, kesan atau respon seseorang dengan tujuan untuk mengetahui secara pasti apa yang ada dalam pikiran setiap individu mengenai suatu objek, bagaimana mereka memahaminya dan apa yang mereka sukai atau yang tidak disukai dari objek tersebut.

\section{a. Pengertian Karakter}

Karakter secara terminologi berarti tingkah laku seseorang yang didorong oleh suatu keinginan secara sadar untuk melakukan suatu perbuatan. ${ }^{10}$ Karakter merupakan nilai-nilai universal perilaku manusia yang meliputi seluruh aktivitas kehidupan, baik yang berhubungan dengan Tuhan, diri sendiri, sesama manusia, maupun dengan lingkungan yang terwujud dalam pikiran, sikap, perasaan, perkataan, dan perbuatan berdasarkan norma-norma

\footnotetext{
${ }^{8}$ Wikipedia, Instagram, 2016, (https://id. wikipedia. org/wiki/Instagram), 02 Januari 2019.

${ }^{9}$ Rama Mukti, Instagram dan Pembentukan Citra (Studi Kualitatif Komunikasi Visual dalam Pembentukan Persolan Karakter Account Instagram @Basukibtp), (Jurnal, Dosen UIN Kalijaga, 2015).

${ }^{10}$ Ahmad A. K. Muda, Kamus Lengkap Bahasa Indonesia. (Jakarta: Reality Publisher, 2006), h. 4550 .
}

agama, hukum, tata krama, budaya, dan adat istiadat. $^{11}$

Pengertian karakter dalam terminologi Islam, memiliki kedekatan pengertian dengan pengertian akhlak. ${ }^{12}$ Kata akhlak berasal dari kata khalaka (bahasa Arab) yang berarti perangai, tabiat dan adat istiadat. Menurut pendekatan etimologi, pendekatan akhlak berasal dari bahasa Arab jamak dari bentuk mufradnya "khuluk" yang berarti budi pekerti, perangai, tingkah laku atau tabiat. ${ }^{13}$ Kalimat ini mengandung segi-segi persesuaian dengan perkataan "khaltum" yang berarti kejadian, serta hubungan perkataan "khalik" yang berarti pencipta dan "makhluk" yang berarti yang diciptakan. $^{14}$

Definisi lain dari karakter yaitu sebuah proses transformasi nilai-nilai kehidupan untuk ditumbuh kembangkan dalam kepribadian seseorang menjadi satu dalam perilaku orang tersebut. ${ }^{15}$

\section{b. Nilai-nilai Karakter}

Penanaman karakter pada peserta didik merupakan hal yang tidak mudah. Karakter peserta didik harusnya tidak hanya mennyentuh segi kognitif saja tetapi harus sampai pengamalan secara nyata serta harus sesuai dengan nilai-nilai Islam. Karakter

\footnotetext{
${ }^{11}$ Suyadi, Strategi Pembelajaran Pendidikan Karakter, (Bandung: PT. Remaja Rosdakarya, 2015), h. 5.

${ }^{12}$ Tim penyusun Kamus Pusat Pembinaan dan Pengembangan Bahasa Depdikbud, Kamus Besar Bahasa Indonesia, (Jakarta: Balai Pustaka, 2006) h. 195.

${ }^{13}$ Luis Ma'ruf, Al-Munjid, (Beirut: al-Makhtab Al-Katulikiyah, t. th), h. 194.

${ }^{14}$ Zharuddin AR dan Hasanuddin Sinaga, Pengantar Studi Akhlak. (Jakarta: Rajawali, t. th) h. 1-2.

${ }^{15}$ Dharma Kesuma, dkk, Pendidikan Karakter, (Bandung: Rosdakarya, 2010), h. 5.
} 
yang baik akan mendorong peserta didik tumbuh dengan sebuah komitmen untuk melakukan hal yang baik dan benar serta memiliki tujuan hidup.

\section{METODE PENELITIAN}

Penelitian ini bersifat kuantitatif, yaitu penelitian yang analisisnya lebih fokus pada data angka (numerian) yang diolah dengan menggunakan metode statistik. Jenis penelitian yang digunakan peneliti adalah penelitian lapangan yaitu penelitian yang dilakukan di kancah atau medan terjadinya gejala. ${ }^{16}$ Peneliti melakukan penelitian langsung ke lokasi untuk mendapatkan data yang ada hubungannya dengan karya ilmiah ini.

Penelitian ini menggunakan metode korelasi yaitu metode dengan menghubungkan antara variabel yang dipilih dan dijelaskan dengan tujuan untuk meneliti sejauh mana variabel pada suatu faktor berkaitan dengan variabel yang lain. ${ }^{17}$ Penelitian dilaksanakan di SMA Negeri 3 Parepare yang berlokasi di Jl. Pendidikan Kelurahan Bukit Harapan Kecamatan Soreang Kota Parepare, Sulawesi Selatan.

Populasi pada penelitian ini mencakup semua peserta didik di kelas X IPA SMA Negeri 3 Parepare yang berjumlah 82 peserta didik. Teknik sampling yang digunakan dalam penelitian ini adalah Random Samplingatau pengambilan sampel secara acak. Sampel penelitian ini adalah peserta didik di kelas X IPA SMA Negeri 3 Parepare dengan jumlah peserta didik sebanyak 46 peserta didik.

Instrumen penelitian yang digunakan penulis dalam penelitian ini

\footnotetext{
${ }^{16}$ M. Iqbal Hasan, Pokok- pokok Materi Metodologi Penelitian dan Aplikasinya, (Jakarta: Ghalia Indonesia, 2002), h. 11.

${ }^{17}$ M. Iqbal Hasan, Pokok- pokok Materi Metodologi Penelitian dan Aplikasinya, h. 23.
}

yaitu pedoman angket/ kuesioner, pedoman wawancara, pedoman observasi. Teknik pengumpulan data yang digunakan dalam penelitian ini menggunakan metode sebagai berikut angket/ kuesioner, wawancara dan dokumentasi. Teknik analisis data yang digunakan dalam menganalisis data yang telah dikumpulkan dalam penelitian ini yaitu statistik deskriptif dan statistik inferensial

\section{HASIL DAN PEMBAHASAN}

\section{Penggunaan Instagram di Kelas $X$ SMA Negeri 3 Parepare}

Pengguna media sosial yang paling dominan saat ini adalah kalangan remaja, baik itu media sosial facebook, twitter, path, line, bahkan youtube. Masing-masing media sosial tersebut memiliki keunggulan yang dapat menarik para pengguna smartphone saat ini khususnya pengguna di kalangan remaja. Media sosial yang paling popular dewasa ini adalah instagram. Popularitas instagram kian menjulang seiring meningkatnya jumlah penggunanya dengan pengguna terbanyak adalah kalangan remaja, termasuk remaja di SMA Negeri 3 Parepare.

Data penggunaan instagram di SMA Negeri 3 Parepare dikumpulkan dengan menggunakan angket/ kuesioner dengan perolehan skor minimal 1 dan maksimal 4. Deskripsi data ini mengambil sampel sebanyak 46 peserta didik, dan peneliti menggunakan rumus frekuensi dan persentase,

$$
\mathbf{P}=\frac{\mathbf{F}}{\mathrm{N}} \mathbf{X} 100
$$

$$
\text { Rekapitulasi frekuensi dan }
$$
persentase jumlah respon untuk variabel $\mathrm{X}$ (Penggunaan instagram) berdasarkan hasil pengolahan data secara statistik deskriptif 
pada angket yang dibagikan dapat dilihat pada grafik batang dan tabel di bawah ini

\section{GRAFIK BATANG REKAPITULASI RESPON} VARIABEL $\mathrm{X}$



REKAPITULASI FREKUENSI DAN

PERSENTASE JUMLAH RESPON

KUESIONER X

\begin{tabular}{|c|c|c|c|c|c|}
\hline $\begin{array}{c}\text { Resp } \\
\text { on }\end{array}$ & $\begin{array}{c}\text { Freku } \\
\text { ensi }\end{array}$ & $\begin{array}{c}\text { Persen } \\
\text { tase }\end{array}$ & $\begin{array}{c}\text { Kateg } \\
\text { ori }\end{array}$ & $\begin{array}{c}\text { Freku } \\
\text { ensi }\end{array}$ & $\begin{array}{c}\text { Persen } \\
\text { tase }\end{array}$ \\
\hline 1 & 86 & $\begin{array}{c}18.7 \\
\%\end{array}$ & $\begin{array}{c}\text { Negat } \\
\text { if }\end{array}$ & 86 & $18.7 \%$ \\
\hline 2 & 208 & $45.2 \%$ & $\begin{array}{c}\text { Seda } \\
\text { ng }\end{array}$ & 208 & $45.2 \%$ \\
\hline 3 & 126 & $27.4 \%$ & $\begin{array}{c}\text { Positi } \\
\mathrm{f}\end{array}$ & 166 & $36.1 \%$ \\
\hline 4 & 40 & $8.7 \%$ & & 460 & $100 \%$ \\
\hline $\begin{array}{c}\text { Tota } \\
\text { l }\end{array}$ & 460 & $100 \%$ & & \multicolumn{3}{|c}{} \\
\cline { 1 - 3 }
\end{tabular}

Berdasarkan grafik batang dan tabel IV. 11 menunjukkan bahwa dari pertanyaan kuesioner variabel $\mathrm{X}$ (penggunaan instagram) kepada 46 responden peserta didik SMA Negeri 3 Parepare adalah pada kategori negatif memiliki frekuensi 86 atau 18, 7\%, kategori sedang (kadang-kadang) memiliki frekuensi 208 atau 45, 2\%, dan kategori positif memiliki frekuensi 166 atau $36,1 \%$.

Bila hasil di atas diinterpretasikan dengan kualifikasi persentase yang didasarkan pada tabel di bawah ini adalah:

\section{INTERVAL PERSENTASE INTESNITAS PENGGUNAAN INSTAGRAM}

\begin{tabular}{|c|c|c|}
\hline No & Persentase (\%) & Klasifikasi \\
\hline 1 & $76 \%$ ke atas & Sangat Tinggi \\
\hline
\end{tabular}

\begin{tabular}{|c|c|c|}
\hline 2 & $51 \%-75 \%$ & Tinggi \\
\hline 3 & $26 \%-50 \%$ & Cukup Tinggi \\
\hline 4 & $25 \%$ ke bawah & Rendah \\
\hline
\end{tabular}

Berdasarkan Tabel IV. 12. di atas dapat dilihat bahwa respon positif dan negatif dengan jumlah 36, $1 \%$ tergolong cukup tinggi dan kategori negatif dengan jumlah 18, 7\% tergolong rendah. Maka hasil kualifikasi positif dan negatif di atas dapat disimpulkan bahwa intensitas penggunaan instagram peserta didik berada pada kategori cukup tinggi yaitu berada pada angka $26 \%$ - 50\% yakni $36,1 \%$.

\section{Karakter Peserta didik di kelas $X$ SMA Negeri 3 Parepare}

Remaja pada hakikatnya sedang berjuang untuk menemukan jati dirinya sendiri, dengan pada dasarnya mudah terpengaruh, suka meniru, dan ingin dianggap paling hebat diantara temannya. Karakter remajapun sangat berbeda-beda, termasuk karakter peserta didik di kelas $\mathrm{X}$ SMA Negeri 3 Parepare.

Rekapitulasi frekuensi dan persentase jumlah respon untuk variabel $\mathrm{Y}$ (Karakter peserta didik) berdasarkan hasil pengolahan data secara statistik deskriptif pada angket yang dibagikan dapat dilihat pada grafik batang dan tabel di bawah ini

\section{GRAFIK BATANG REKAPITULASI RESPON VARIABEL Y}

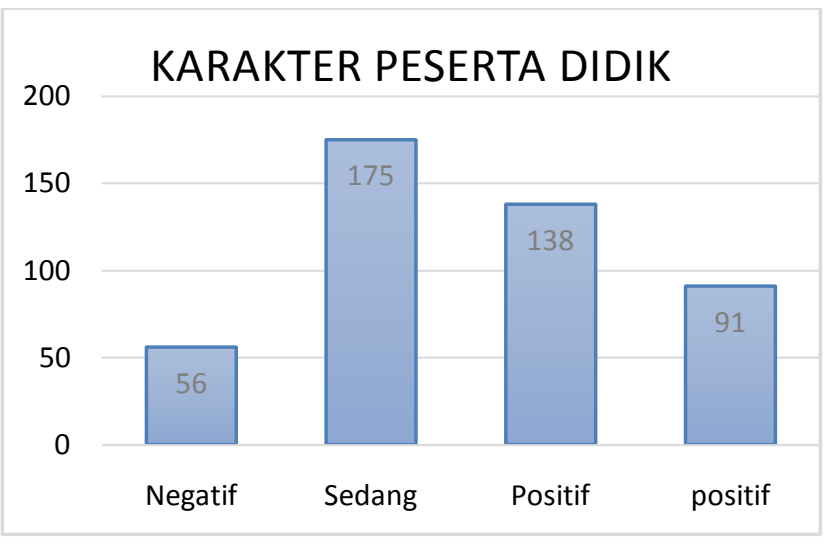


REKAPITULASI FREKUENSI DAN

PERSENTASE JUMLAH RESPON

KUESIONER Y

\begin{tabular}{|c|c|c|c|c|c|}
\hline $\begin{array}{c}\text { Resp } \\
\text { on }\end{array}$ & $\begin{array}{c}\text { Freku } \\
\text { ensi }\end{array}$ & $\begin{array}{c}\text { Persen } \\
\text { tase }\end{array}$ & $\begin{array}{c}\text { Kateg } \\
\text { ori }\end{array}$ & $\begin{array}{c}\text { Freku } \\
\text { ensi }\end{array}$ & $\begin{array}{c}\text { Persen } \\
\text { tase }\end{array}$ \\
\hline 1 & 56 & $12.2 \%$ & $\begin{array}{c}\text { Negat } \\
\text { if }\end{array}$ & 56 & 12. $2 \%$ \\
\hline 2 & 175 & $38 \%$ & $\begin{array}{c}\text { Seda } \\
\text { ng }\end{array}$ & 175 & $38 \%$ \\
\hline 3 & 138 & $30 \%$ & \multirow{2}{*}{$\begin{array}{c}\text { Positi } \\
\text { f }\end{array}$} & \multirow{2}{*}{229} & \multirow{2}{*}{ 49. $8 \%$} \\
\hline 4 & 91 & $19.8 \%$ & & & \\
\hline $\begin{array}{c}\text { Tota } \\
1\end{array}$ & 460 & $100 \%$ & & 460 & $100 \%$ \\
\hline
\end{tabular}

Berdasarkan grafik batang dan tabel IV. 23 di atas menunjukkan bahwa dari pertanyaan kuesioner variabel Y (karakter peserta didik) kepada 46 responden peserta didik SMA Negeri 3 Parepare adalah pada kategori negatif memiliki frekuensi 56 atau 12, 2\%, kategori sedang (kadang-kadang) memiliki frekuensi 175 atau 38\%, dan kategori positif memiliki frekuensi 229 atau 49, $8 \%$.

Bila hasil di atas diinterpretasikan dengan kualifikasi persentase yang didasarkan pada tabel di bawah ini adalah:

INTERVAL PERSENTASE KARAKTER PESERTA DIDIK

\begin{tabular}{|c|c|c|}
\hline No & Persentase (\%) & Klasifikasi \\
\hline 1 & $76 \%$ ke atas & Sangat Baik \\
\hline 2 & $51 \%-75 \%$ & Baik \\
\hline 3 & $26 \%-50 \%$ & Cukup Baik \\
\hline 4 & $25 \%$ ke bawah & Kurang Baik \\
\hline
\end{tabular}

Berdasarkan tabel diatas dapat dilihat bahwa respon positif dan negatif dengan jumlah 49, 8\% tergolong cukup baik dan kategori negatif dengan jumlah 12, 2\% tergolong kurang baik. Maka hasil kualifikasi positif dan negatif di atas dapat disimpulkan bahwa karakter peserta didik berada pada kategori cukup baik yang berada pada angka 26\% - 50\% yakni 49, $8 \%$.

\section{Pengaruh Penggunaan Instagram terhadap Pembentukan Karakter di Kelas X SMA Negeri 3 Parepare}

Penelitian ini terdiri dari dua variabel $\mathrm{X}$ (penggunaan instagram) dan variabel Y (karakter peserta didik) sebagai variabel bebas dan variabel terikat. Untuk mengetahui tingkat pengaruh antara variabel penggunaan Instagram (X) terhadap karakter peserta didik (Y), maka akan dibuktikan melalui perhitungan secara statistik dengan menggunakan rumus korelasi product moment dan analisis statistik inferensial dengan alat analisis regresi linear sederhana dengan sepenuhnya menggunakan program SPSS 23.

Analisis regresi linear sederhana dilakukan peneliti untuk mengetahui lebih jelas seberapa besar hubungan antar variabel pengaruh penggunaan instagram dan variabel pembentukan karater peserta didik. Hasil analisis uji regresi linear sederhana adalah sebagai berikut:

\section{Coefficients $^{\mathrm{a}}$}

\begin{tabular}{|c|c|c|c|c|c|}
\hline \multirow[t]{2}{*}{ Model } & \multicolumn{2}{|c|}{$\begin{array}{l}\text { Unstandardi } \\
\text { zed } \\
\text { Coefficients }\end{array}$} & \begin{tabular}{|c} 
Standardiz \\
ed \\
Coefficien \\
ts \\
\end{tabular} & $\mathrm{T}$ & $\mathrm{Si}$ \\
\hline & B & $\begin{array}{c}\text { Std. } \\
\text { Erro } \\
\mathrm{r}\end{array}$ & Beta & & \\
\hline $\begin{array}{l}1 \text { (Consta } \\
\text { nt) } \\
\\
\text { Instagra } \\
m\end{array}$ & 20.754 & $\begin{array}{r}1 . \\
862\end{array}$ & .382 & $\begin{array}{r}14 \\
4 \\
2 . \\
73 \\
9\end{array}$ & 009 \\
\hline
\end{tabular}

Model Summary 


\begin{tabular}{|l|r|r|r|l|}
\hline Model & $\mathrm{R}$ & $\begin{array}{c}\mathrm{R} \\
\text { Square }\end{array}$ & $\begin{array}{c}\text { Adjusted } \\
\mathrm{R} \\
\text { Square }\end{array}$ & $\begin{array}{c}\text { Std. } \\
\text { Error of } \\
\text { the } \\
\text { Estimate }\end{array}$ \\
\hline 1 & $382^{\mathrm{a}}$ & .146 & .126 & 2.66903 \\
\hline
\end{tabular}

a. Predictors: (Constant), Penggunaan Instagram

b. Dependent Variable: Karakter Peserta Didik

Hasil uji analisis di atas menunjukkan bahwa terdapat korelasi atau hubungan antara penggunaan instagram terhadap pembentukan karakter peserta didik yaitu sebesar 0, 382. Angka tersebut menunjukkan adanya korelasi positif antara variabel $\mathrm{X}$ (penggunaan instagram) dengan variabel Y (karakter peserta didik) jika dibandingkan dengan koefisien product moment (r) pada tabel yakni sebesar 0, 290.

Untuk mengetahui besarnya hubungan antara variabel bebas dengan variabel terikat, dapat dilihat pada tabel interpretasi nilai $r$ sebagai berikut:

TABEL INTERPRETASI NILAI $\mathrm{r}$

\begin{tabular}{|c|c|}
\hline Koefisien Korelasi & Klasifikasi \\
\hline$>100$ & Sempurna \\
\hline $0,81-1,00$ & Sangat Tinggi \\
\hline $0,61-0,80$ & Tinggi \\
\hline $0,41-0,60$ & Cukup Tinggi \\
\hline $0,21-0,40$ & Rendah \\
\hline $0,00-0,20$ & Sangat Rendah \\
\hline
\end{tabular}

Berdasarkan pedoman interpretasi koefisien korelasi di atas, maka indeks korelasi product moment yang terletak pada angka0, 21-0, 40 berada pada kategori rendah. Dengan demikian, dapat disimpulkan bahwa korelasi antara variabel $\mathrm{X}$ (penggunaan instagram) dan variabel $\mathrm{Y}$ (karakter peserta didik) adalah terdapat korelasi yang rendah, yaitu sebesar 0, 382 .
Sedangkan kontribusi yang diberikan oleh variabel penggunaan instagram terhadap pembentukan karakter peserta didik sebesar 14, 6\% sedangkan sisanya (100\%-14, 6\%) adalah 85, 4\% dipengaruhi oleh varibel lain di luar penelitian ini yang ditunjukkan oleh variabel $\mathrm{R}$ squaredi atas.

Berdasarkan tabel IV. 25 di atas dapat juga diketahui nilai persamaan regresi linear sederhana antara Penggunaan Instagram (X) dengan Karakter Peserta Didik (Y) di SMA Negeri 3 Parepare. Nilai persamaan regresi tersebut adalah:

$$
\begin{aligned}
& \dot{Y}=\alpha+b X \\
& \dot{Y}=20.754+0,220 X
\end{aligned}
$$

Persamaan di atas memiliki arti bahwa nilai konsisten variabel Y (Karakter) yakni sebesar 20, 754. Jadi setiap penambahan $1 \%$ nilai penggunaan instagram maka nilai karakter peserta didik bertambah sebesar 0,220. Koefisien regresi tersebut bernilai positif sehingga dapat dikatakan bahwa arah pengaruh variabel $\mathrm{X}$ terhadap Y adalah positif.

\section{Penggunaan Instagram di Kelas X SMA Negeri 3 Parepare}

Berdasarkan hasil observasi yang dilakukan oleh peneliti diSMA Negeri 3 Parepare ditemukan bahwa peserta didik cukup sering dalam menggunakan instagram namun tidak begitu intens. Peserta didik biasanya menggunakan instagram untuk melakukan berbagai hal seperti membaca postingan motivasi dan dakwah, menonton video, me-like postingan dakwah, mengikuti atau memfollow akun publik figur, dan lain-lain.

Berdasarkan wawancara yang telah dilakukan peneliti kepada beberapa peserta didik mengenai penggunaan instagram, peserta didik Zulkifli mengungkapkan bahwa instagram merupakan media sosial 
yang saat ini sering digunakan, tidak hanya sekedar berkomunikasi dengan teman yang berada di daerah yang lain tetapi juga untuk mencari informasi yang baru. Jika memiliki waktu luang biasanya dihabiskan dengan membaca atau menonton postingan yang ada di Instagram, mencari trend-trend yang sedang viral, dan juga mengomentari postingan teman yang diikuti di instagram. Tidak hanya itu tetapi juga kadang-kadang mengunggah foto atau video. Namun, tidak menutup kemungkinan peserta didik juga menemukan hal-hal berbau negatif seperti foto- foto fulgar dari akun yang tidak diketahui. $^{18}$

Sedangkan peserta didik Intan Nur Aini mengatakan bahwa tidak jarang terdapat konten-konten berbau hoax di instagram serta komentar-komentar kasar dari pengguna instagram lainnya dalam sebuah postingan foto. Hal tersebut sangat berbahaya bagi remaja-remaja lain yang memiliki mental lemah. Namun, apabila instagram digunakan dengan cara yang baik seperti menyebarkan kebahagiaan kepada orang lain maka hal tersebut akan memberi dampak positif bagi remaja pengguna instagram. Banyak sekali hal yang dapat kita pelajari dari instagram seperti tutorial make up, video-video penyemangat, hingga mengetahui hal-hal yang sedang banyak diperbincangkan oleh orang-orang. ${ }^{19}$

Berdasarkan wawancara yang dilakukan penulis terhadap kedua peserta didik tersebut, dapat diketahui bahwa instagram saat ini menjadi sosial media yang cukup sering diakses oleh peserta didik. Tersedianya berbagai macam fitur di

\footnotetext{
${ }^{18}$ Zulkifli Peserta didik kelas X, Wawancara oleh penulis di ruangan kelas X, Tanggal 12 Maret 2019.

${ }^{19}$ Intan Nur Aini Peserta didik kelas X, Wawancara oleh penulis di ruangan kelas X, Tanggal 12 Maret 2019.
}

sosial media ini menjadi daya tarik tersendiri bagi peserta didik seperti fitur menunggah video atau foto, mengunduh video serta mengikuti akun-akun yang disukai, bahkan mengomentari sebuah postingan. Namun, terdapat pula dampak negatif dari penggunaan instagram seperti banyaknya ujaran- ujaran kebencian, hoax,hingga konten-konten pornografi.

Sebagaimana dinyatakan oleh Bagus Wibowo, bahwa ada dua faktor yang dapat mengatasi dampak negatif dari instagram, pertama dari faktor intern (dalam) atau pengendalian dari diri sendiri, kedua dari faktor ekstern (luar) atau pengendalian yang dipengaruhi orang lain. ${ }^{20}$ Faktor intern mengandung arti bahwa dalam mencegah ataupun mengatasi dampak negatif yang telah maupun yang akan terjadi dapat dikendalikan melalui kesadaran dari pengguna instagram itu sendiri. Bagaimanapun intensnya dia dalam menggunakan sosial media tersebut tidak akan berdampak negatif pada dirinya selama dia mampu memilah konten yang bisa mendatangkan pengaruh positif untuk dirinya.

Sedangkan pengaruh ektern mengandung arti bahwa dampak negatif yang ditimbulkan oleh instagram dapat dicegah atau diatasi dengan bantuan orang lain. Bantuan tersebut dapat berupa kritikan maupun masukan atau nasihat dari orang lain yang memiliki kepedulian terhadap perkembangan teknologi yang semakin canggih dan global ini.

Analisis deskriptif pada penelitian ini, yakni hasil dari penggunaan instagram menunjukkan bahwa intensitas penggunaan instagram pada peserta didik kelas X SMA Negeri 3 Parepare termasuk dalam kategori

\footnotetext{
${ }^{20}$ Bagus Wibowo, Tentang Sosial Media, 2018, (https://www. kompasiana. com/baguswibowo), diakses pada tanggal 15 Juni 2019
} 
cukup tinggi. Hal ini terbukti dengan hasil angket yang memiliki nilai rata-rata 45 . $2 \%$. Nilai tersebut berada dalam interval 26\% $50 \%$ yang masuk dalam kategori cukup tinggi.

Berdasarkan rangkuman hasil wawancara dan obeservasi yang telah dilakukan peneliti diperoleh keterangan bahwa peserta didik kelas X SMA Negeri 3 Parepare tergolong pengguna instagram yang cukup aktif. Fitur-fitur lengkap serta up to date yang ada di instagram menjadi salah satu daya tarik tersendiri bagi peserta didik. Bukan hanya sebagai media komunikasi tetapi juga dapat menambah wawasan yang bersifat edukatif bagi peserta didik. Terbukti dari fitur explore yang ada di instagram yang memungkinkan peserta didik mencari informasi mengenai materi pelajaran yang ada di sekolah.

\section{Karakter Peserta Didik di Kelas X SMA Negeri 3 Parepare}

Karakter dapat juga diartikan sebagai akhlak atau budi pekerti, sehingga karakter bangsa identik dengan akhlak bangsa atau budi pekerti bangsa. Bangsa yang berkarakter adalah bangsa yang berakhlak dan berbudi pekerti, sebaliknya bangsa yang tidak berkarakter adalah bangsa yang tidak mempunyai akhlak atau budi pekerti dan juga tidak mempunyai standar norma dan perilaku yang baik.

Karakter peserta didik di SMA Negeri 3 Parepare cukup baik. Hal tesebut terbukti dari hasil observasi yang peneliti lakukan di lapangan. Dari hasil observasi peneliti mengamati bahwa peserta didik memiliki karakter yang cukup baik. Hal tersebut tampak dari perilaku peserta didik yang sopan ketika berinteraksi dengan teman, cara berpakaian yang rapi, serta tutur kata yang baik terhadap lawan bicaranya.
Peserta didik kelas X khususnya kelas IPA memiliki karakter yang cukup mudah diatur, hal tersebut mungkin karena mereka masih menyesuaikan diri dengan kehidupan tingkat sekolah yang lebih tinggi, tidak seperti senior mereka yang kadang sangat susah untuk diatur. Peserta didik saat ini juga sangat mengikuti perkembangan zaman, terlihat dari semua peserta didik yang membawa smartphone ke sekolah meskipun sebenarnya hal tersebut merupakan hal yang kurang baik karna dapat mengganggu pembelajaran. Namun, yang paling berperan dalam pembentukkan karakter peserta didik adalah guru. ${ }^{21}$

Pada hasil wawancara di atas dapat diketahui bahwa karakter yang dimiliki peserta didik kelas X SMA Negeri 3 Parepare cukup baik. Hal tersebut dilihat dari sikap peserta didik dalam bertutur kata yang sopan kepada sesama temannya serta juga kepada gurunya. Meskipun tidak menutup kemungkinan bahwa masih ada siswa yang memiliki karakter kurang baik.

Guru memegang peranan yang sangat penting terutama dalam pembentukan karakter serta mengembangkan potensi siswa. Keberadaan guru di tengah masyarakat dapat dijadikan teladan dan rujukan masyarakat sekitar. Dapat dikiaskan, guru adalah penebar cahaya kebenaran dan keagungan nilai. Hal inilah yang menjadikan guru untuk selalu on the right track, pada jalan yang benar, tidak menyimpang dan berbelok, sesuai dengan ajaran agama yang suci, adat istiadat yang baik dan aturan pemerintah.

Analisis deskriptif pada penelitian ini menunjukkan bahwa karakter peserta didik di SMA Negeri 3 Parepare termasuk

\footnotetext{
${ }^{21}$ Hartina Guru PAI, Wawancara oleh penulis di mushallah sekolah, tanggal 12 Maret 2019.
} 
dalam kategori baik. Hal ini terbukti dengan hasil angket yang memiliki nilai rata-rata 49 , $8 \%$. Nilai tersebut berada dalam interval 26\%-50\% yang masuk dalam kategori cukup baik. Dari rangkuman hasil wawancara dan observasi yang telah dilakukan diperoleh keterangan tambahan bahwa karakter yang dimiliki peserta didik dalam kelas sangat bermacam-macam. Sebagian peserta didik sangat menghormati gurunya, sebagian pula ada yang susah untuk diatur. Karakter yang dimiliki peserta didik di kelas X SMA Negeri 3 parepare cukup baik dilihat dari cara mereka berinteraksi dengan sopan kepada teman dan guru, cara mereka berpakaian secara rapi, serta tingkah laku mereka yang sebagian besar mencerminkan karakter Islami.

\section{Pengaruh Penggunaan Instagram Terhadap Pembentukan Karakter Peserta didik di Kelas X SMA Negeri 3 Parepare}

Instagram merupakan media sosial yang paling populer, dengan berbagai kelebihan yang disajikan membuat popularitas instagram kian menjulang, seiring dengan meningkatnya jumlah penggunanya. Jumlah pengguna aplikasi tersebut sangat mengalami peningkatan yang signifikan dengan pengguna terbanyak adalah kalangan remaja.

Kemudahandan dampak positif yang dihasilkan media sosial instagrammembuat pengguna juga tak terlepas dari unsur negatif, contohnya seperti tidak adanya kepedulian terhadap sekitar mereka, mengikuti yang sedang mereka lihat pada media sosial instagram, bahkan mereka melalaikan kewajiban mereka dalam urusan agama. Namun, apabila para peserta didik dapat menyikapi manfaat dari media sosial instagramtersebut maka hal-hal yang bersifat negatif tersebut dapat dikurangi dan menjadi hal-hal yang bersifat positif.

Media sosial instagram bukan hanya sebagai media bereksistensi tetapi juga dapat dimanfaatkan sebagai wadah untuk berdakwah, seperti berbagi foto dan video yang berisi tentang keislaman, tidak berlebihan dalan hal duniawi, ukhuwah islamiyah, pentingnya beribadah kepada Allah SWT. dan menghormati orangtua. Sedangkan karakter adalah tindakan, aktifitas maupun tingkahlaku remaja yang mencerminkan nilai-nilai keislaman dalam kehidupan sehari-harinya.

Pengaruh penggunaan instagram terhadap karakter peserta didik kelas $\mathrm{X}$ di SMA Negeri 3 Parepare dapat disimpulkan bahwa korelasi antara variabel $\mathrm{X}$ (penggunaan intagram) dan variabel $\mathrm{Y}$ (karakter peserta didik) memiliki korelasi positif namun terbilang rendah. Hal tersebut berdasarkan perhitungan dengan menggunakan teknik korelasi product moment dengan program aplikasi SPSS 23.

Berdasarkan observasi yang telah dilakukan peneliti diperoleh keterangan tambahan yaitu karakter peserta didik bukan hanya dipengaruhi oleh sosial media, tetapi juga dipengaruhi oleh teman sebaya mereka. Apabila pergaulan mereka baik, maka karakter yang dihasilkan akan baik pula. Namun tidak menutup kemungkinan bahwa seiring dengan perkembangan teknologi di masa yang akan datang, penggunaan instagram akan sangat berpengaruh terhadap karakter peserta didik, baik itu berpengaruh positif ataupun negatif terhadap karakter peserta didik.

\section{Pengujian Hipotesis}

Hubungan antara dua variabel, dapat dilakukan dengan cara membandingkan nilai $\mathrm{r}_{\mathrm{h}}$ dengan nilai " $\mathrm{r}$ " prodect moment 
dalam tabel, pada taraf signifikan 5\% dengan ketentuan sebagai berikut:

Jika $\left|r_{h}\right|>r_{t}$, maka menolak $H_{o}$ atau menerima $\mathrm{H}_{\mathrm{a}}$

Jika $\left|r_{h}\right|<r_{t}$, maka menerima $H_{o}$ atau menolak $\mathrm{H}_{\mathrm{a}}$

Berikut ini adalah rumusan hipotesis yang peneliti ajukan:

$\mathrm{H}_{\mathrm{a}}$ : Penggunaan instagram berpengaruh terhadap karakter peserta didik.

Nilai $r_{h}$ lebih besar dari taraf signifikan 5\%. Oleh karena itu dapat disimpulkan bahwa terdapat korelasi positif yang antara penggunaan instagram dengan pembentukan karakter peserta didik di kelas X SMA Negeri 3 Parepare.

Berdasarkan analisis diatas, maka hipotesis yang peneliti ajukan diterima. Yaitu ada pengaruh antara penggunaan instagram terhadap pembentukan karakter peserta didik di kelas X SMA Negeri 3 Parepare. Salah satu hal yang bisa dilakukan dalam mengatasi pengaruh penggunaan instagram terhadap pembentukan karakter peserta didik yaitu adanya kerja sama yang baik antara orangtua, guru, dan masyarakat sehingga dengan kerjasama tersebut dapat membangun lingkungan yang mendukung pembentukan karakter yang islami.

\section{Kesimpulan}

1. Intensitas penggunaan instagram peserta didik di kelas $\mathrm{X}$ termasuk dalam kategori cukup tinggi. Hal ini terbukti dengan hasil angket yang memiliki nilai rata-rata $45.2 \%$. Nilai tersebut berada dalam interval 26\% $50 \%$ yang masuk dalam kategori cukup tinggi. Banyak hal positif yang dapat diambil dari instagram seperti memudahkan pengguna internet untuk berkomunikasi dengan teman yang berada di daerah yang jauh, banyaknya postinganpostingan yang dapat memotivasi pengguna serta informasi-informasi yang up to date. Selain dampak positif yang dihasilkan instagram, terdapat pula dampak negative seperti banyaknya ujaran kebencian dari pengguna instagram yang lain serta hoaxyang tersebar tanpa diketahui kebenarannya.

2. Karakter peserta didik di kelas $\mathrm{X}$ SMA Negeri 3 Parepare termasuk dalam kategori cukup baik. Hal ini terbukti dengan hasil angket yang memiliki nilai rata-rata 49,8\%. Nilai tersebut berada dalam interval 26\%$50 \%$ yang masuk dalam kategori cukupbaik. Karakter pada peserta didik dalam penelitian ini dikategorikan ke dalam 3 indikator yakni cara bertutur kata, tingkah laku, serta cara berpakaian. Implementasi pendidikan karakter dalam Islam, tersimpul dalam karakter pribadi Rasulullah SAW. dalam pribadi Rasul, tersemai nilai-nilai akhlak yang mulia dan agung

3. Pengaruh penggunaan instagram terhadap karakter peserta didik di kelas X SMA Negeri 3 Parepare dapat disimpulkan bahwa terdapat korelasi berdasarkan perhitungan dengan menggunakan teknik korelasi product moment dan teknik wawancara. Secara umum intensitas penggunaan instagram cukup tinggi di kelas X SMA Negeri 3 Parepare. Hal ini terbukti dengan hasil angket yang memiliki nilai rata-rata $45.2 \%$. Nilai tersebut berada dalam interval $26 \%-50 \%$ yang masuk dalam kategori cukup tinggi. Instagram dapat memberi dampak terhadap 
gaya hidup remaja baik positif maupun negatif.

\section{DAFTAR PUSTAKA}

Arikunto, Suharsimi. Prosedur Penelitian Suatu Pendekatan Praktik. Cet. XIII: Jakarta: Rineka Cipta, 2006.

AR, Zharudin, dan Hasanuddin Sinaga. Pengantar Studi Akhlak. Jakarta: Rajawali, 2015.

Atmoko, Bambang Dwi Instagram Handbook Tips Fotografi Ponsel. Jakarta: Media Kita, 2012.

Bungin, Burhan. Metodologi Penelitian Kuantitatif; Komunikasi, Ekonomi dan Kebijakan Publik Serta Ilmuilmu Sosial Lainnya. Jakarta: Kencana Prenada Media. 2014.

Das, Wardah Hanafie dan Abdul Halik. Kiat Menulis Karya Ilmiah. Makassar: Alauddin University Press. 2016.

Departemen Agama RI, Al-Qur'an dan Terjemahnya, Bandung, PT. Sygma Examedia Arkanleema, 2009.

Ferlitasari, Reni. Pengaruh Media Sosial Instagram Terhadap Perilaku Keagamaan Remaja, Skripsi Sarjana UIN Raden Intan, Lampung, 2018.

Hartono, SPSS 16. 0: Analisis Data Statistika dan Penelitian. Yogyakarta: Pustaka Pelajar. 2010.

Hasan, M. Iqbal. Pokok-pokok Materi Metodologi Penelitian dan Aplikasinya, Jakarta: Ghalia Indonesia, 2002.

Hawassy, Ahmad. Kajian Akhlak dalam Bingkai Aswaja, Banten:Genggambuk E-Publisher, 2018.
Kesuma, Dharma dkk. Pendidikan Karakter. Bandung: Rosdakarya, 2010

Mubarak, Zakky, dkk. Manusia, Akhlak, Budi Pekerti dan Masyarakat. Buku Ajar II Mata Kuliah Pengembangan Kepribadian Terintegrasi Fakultas Ekonomi Universitas Indonesia Depok, 2008.

Muda, Ahmad A. K. , Kamus Lengkap Bahasa Indonesia. Jakarta: Reality Publisher, 2006.

Mukti, Rama. Instagram dan Pembentukan Citra (Studi Kualitatif Komunikasi Visual dalam Pembentukan Persoalan Karakter Account Instagram @Basukibtp, Jurnal, Dosen UIN Sunan Kalijaga, 2015.

Ma'ruf, Luis. Al-Munjid, Beirut: alMakhtab Al-Katulikiyah. t. th.

Nasrullah, Rulli. Teori dan Riset Media Siber (Cybermedia), Jakarta: Prenadameida Group, 2014.

Noerjanah, 2014, Jenis-jenis Peneitian. https://www. academia. edu. Diakses pada 6 Desember 2018.

Pangesti, Sri, dkk. Metode Statistika Yogyakarta: Gama Press, 2004.

Putri, Vindisiari. Aturan UU IT, 2017, (https://www. brilio. net/serius/6aturan-di-uu-ite-ini-perlu-kamutahu-agar-aman-saat-bermedsos. html), diakses pada 29 Desember 2018.

Rakhmat, Jalaludin, Metode Penelitian Komunikasi, (Bandung: Rosdakarya, 1999).

Republik Indonesia, Undang-Undang RI. Nomor 20 Tahun 2003 tentang 
Sistem Pendidikan Nasional, bab II, pasal 3 ayat 1.

Riduwan, Adun Rusyana dan Anas. Cara Mudah Belajar SPSS 17. 0 dan Aplikasi Statistik Penelitian. Cet. I; Bandung: Alfabeta, 2011.

Riduwan dan Sunarto, Pengantar Statistika. Bandung: Alfabeta, 2009.

Riduwan, Skala Pengukuran VariabelVariabel Penelitian. Cet. VII; Bandung: Alfabeta, 2010.

Sarwono, Jonathan. Metode Penelitian Kuantitatif \& Kualitatif, Bandung: Graha Ilmu, 2006.

Singarimbun, Masri dan Sofian Effendi, Metode Penelitian Survey, Jakarta: LP3ES, 2011.

Sugiono, Metode Penelitian Manajemen. Bandung: Alfabetha, 2013.
Suyadi, Strategi Pembelajaran Pendidikan Karakter, Bandung: PT. Remaja Rosdakarya, 2015.

Tamburaka, Apriadi. Literasi Media; Cerdas Bermedia Khalayak Media Massa, Jakarta; PT Rajagrafindo Persada, 2013.

Wibowo, Bagus. Tentang Sosial Media. 2018. (http://www. kompasiana. com/baguswibowo), Diakses pada tanggal 15 Juni 2019

Wifalin, Michelle. Efektivitas Instagram Common Grounds, Jurnal EKomunikasi ProgramStudi Ilmu Komunikasi Universitas Petra Surabaya.

Wikipedia, Instagram, 2016, https://id. wikipedia. org/wiki/Instagram. Diakses pada 14 Desember 2018. 